\title{
The Contribution Of Organisational Climate To Employee Well-Being
}

\author{
Dr. Chengedzai Mafini, Vaal University of Technology, South Africa
}

\begin{abstract}
There is ample space for further human resource based research in the service industry sector in South Africa. For that reason, this study developed and tested a conceptual framework that linked employee well-being to four organisational climate factors; namely, manager-employee relationships, working conditions, remuneration and work allocation. An adapted six section structured questionnaire was administered to a conveniently recruited sample composed of 164 employees drawn from seven service industry enterprises located in Southern Gauteng, South Africa. Hypotheses were tested using regression analysis. All four organisational climate dimensions were statistically significant, implying that they predict employee well-being in the service industry. The results of this study may be used by managers in similar environments as either diagnostic tools or as a reference benchmark for strategic interventions in solving employee well-being related problems.
\end{abstract}

Keywords: Management-Employee Relationship; Working Conditions; Remuneration; Teamwork; Work Allocation; Employee Well-Being; Service Industry; South Africa

\section{INTRODUCTION}

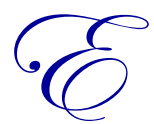

mployee well-being in the service industry is an insightful and interesting area of study. Success in the services sector hinges on the quality of service provided by each establishment, and this to a large extent, is determined by employees who form the front line contact with clients. Having dissatisfied employees in the service industry may be equated to irresponsibility, since disgruntled employees are prone to pass on their dissatisfaction to clients. This obviously negatively affects customer satisfaction and loyalty, which has a ripple effect on profits and overall prosperity of enterprises in this sector. In light of this, it is paramount to direct attention to the well-being of employees in business enterprises operating in the service sector in order to generate current information on how to improve it for the benefit of each enterprise.

Against the above-chronicled backdrop, this study developed and tested a conceptual framework (refer to Figure 1) proposing that employee well-being is predicted by four organisational climate factors; specifically, manageremployee relationships, working conditions, remuneration, and work allocation. Employee well-being cannot be improved unless its antecedents are known. In this study, four of these antecedents are identified and their ability to predict employee well-being within the context of the South African service industry sector is tested. The study presents possibilities of either endorsing or contradicting previous results on the ability of these factors to predict employee well-being. The apparent paucity of studies that have developed and tested a similar conceptual framework in the context of developing countries in Sub-Saharan Africa provided a fundamental impetus to this study.

\section{LITERATURE REVIEW AND HYPOTHESES FORMULATION}

\subsection{Employee Well-Being}

In this study, employee well-being was considered to be a pleasurable or positive emotional state resulting from the appraisal of one's job or job experiences (Locke, 1969). Employee well-being also pertains to an individual's perception and evaluation of his job and this perception is influenced by the person's unique circumstances such as needs, values and expectations (Buitendach \& De Witte, 2005). It emphasises the general internal state of satisfaction or dissatisfaction within the individual (Thompson \& Phua, 2012). High employee well-being is a product of such factors as affirmative social intercourse, adequate pay, remuneration, empathetic superiors as well as attractive 
working conditions (Giannikis \& Mihail, 2011). In other words, employee well-being increases when an individual's work environment fulfils his/her needs, values and personal characteristics (Yee, Yeung \& Cheng, 2010). The results of employee well-being include higher commitment, higher employee productivity, increased organisational citizenship behaviours and decreased turnover/ intention to quit (Agarwal \& Ferratt, 2001). It is widely considered wise for organisations to endeavour to ensure that their employees are happy, as this gives yield to an assortment of pertinent benefits to the organisation (Price, 2001).

\subsection{Organisational Climate}

Organisational climate is a description of the members' perception of their work environment (Zhang \& Liu, 2010). It is a set of properties of the work environment, perceived directly or indirectly by the employees, that is assumed to be a major force in influencing employee behaviour (Ivancevich, Konopaske \& Matteson, 2007). Two basic perspectives of organisational climate are apparent. The first is the macro mode, which focuses on the organisational climate individuals perceive in the entire work environment (Hunter, Bedell \& Mumford, 2007). The second is the micro mode, which is aimed at a certain dimension or a certain environment of the organisation (Tang \& Chen, 2001). In the last two decades, human resources management situations have emerged as the climate issues that members of organisations were most concerned about (Bushell, 2007). These issues which include inter alia; recruitment, selection, training, remuneration, performance management relationship with managers, workplace conditions, management appraisal and benefits, are all closely associated with the crucial interests of employees (Rose \& Waterhouse, 2004). For this reason, human resources management style and its operational approach are crucial to the way employees perceive organisational climate, and are regarded as significant factors affecting organisational climate (Jackson \& Schuler, 1995).

\subsection{Manager-Employee Relationships}

There are a number of dominant internal relationships in any organisation, with relationships amongst employees, between employees and supervisors and between employees and functional departments being standard examples (Nielsen, Yarker, Brenners, Randall \& Borg, 2008). Among these, the relationship between employees and their managers is arguably one of the most critical (Yeow \& Sen, 2006). The right treatment of employees is the first market of the organisation (Bhattacharya \& SankarSen, 2003). Hence, the creation and management of acceptable internal relationships between management and employees is regarded as a critical activity (Voss, Cable \& Voss, 2006).

A study by Nielsen et al. (2008) found a positive relationship between management style and employee well-being through mediation from work characteristics. Consistently, Bono and Ilies (2006) concluded that that proper management styles create a positive emotion and mood among employees. Gilbreath and Benson (2004) further opine that supervisory behaviour is the most overriding factor compared with other workplace factors that influence the happiness of employees. This challenges managers to positively acknowledge the role played by employees and to develop management styles and demeanours that facilitate the satisfaction of the needs of employees in order to ensure that the performance of the organisation is improved (Martins, 2005). Based on the aforementioned empirical results, the following hypothesis is put forward:

H1: There is a significant relationship between manager-employee relationship and employee well-being in the service industry

\subsection{Working Conditions}

Working conditions may be perceived as the circumstances under which the employee works (Forlan \& Browne, 2005). These consist of the surroundings that influence an individual at work, with examples being facilities, physical environment, and the degree of safety and noise levels (Nurmala, 2010). Rethinam and Ismail (2008) suggest that working conditions involve promoting a work environment that is conducive to the satisfaction of employees' needs. Md-Sidin, Sambasivan and Ismail (2010) view working conditions as a comprehensive factor that includes an individual's job-related well-being and the extent to which work experiences are rewarding, fulfilling and devoid of stress and other negative personal consequences. Yavari, Amirtash and Tondnevis (2009) further state that working conditions capture the degree to which the, job requirements, management behaviour, ancillary programs and the 
general work environment in an organisation meet the needs of an employee. This demonstrates the import of working conditions to the well-being of both the employee and the organisation.

According to Mead, Witkowski, Gault and Hartmann (2003), working conditions are linked to the health and welfare of employees. Fabiano, Curro, Reverberi and Pastorino (2008) further opine that stress which leads to depressive and anxiety disorders may typically be a result of unsatisfactory working conditions. Working conditions possibly linked to employee health behaviours include working overtime, work fatigue, physically strenuous work and mentally strenuous work (Holcroft \& Punnett, 2009). Moreover, Varonen and Mattila (2003) emphasise the importance of safety climate, showing that the more safety-conscious the climate of the company, the lower the accident rate. Issues such as physical workload, machine-paced work or the inability to take a break when tired, lack of training, absence of a lockout program, low seniority and gender are also associated with high injury risk through accidents (Tangen, 2004). It becomes advisable then for organisations to improve the working conditions of employees by ensuring that safety training is given to employees (Attwood, Khan \& Veitch, 2006). In view of these results, the following hypothesis is suggested:

H2: There is a significant relationship between working conditions and employee well-being in the service industry

\subsection{Remuneration}

Remuneration may be defined as the reward given to employees for performing their work (Schutte \& Eaton, 2004). Most successes or problems in organisations can be traced back to the level of satisfaction with employee rewards as well as the competency of human resources (Katou \& Budhwar, 2007). Guthrie and English (1997) specify that organisations recognise that people are the real agents in business and that all structures and assets, both tangible as well as intangible, are a result of human actions. This could explain why most organisations locally and internationally invest astronomical amounts of money in attracting and placing human talent (Ireland, Hoskisson \& Hitt, 2009).

Remuneration remains an important source of motivation for employees since it defines their standard of living. Remuneration is a factor in employee retention because it is a component of job satisfaction (Cropanzano \& Mitchell, 2005). It is a factor in career choice, as well as the salary gradient between positions and practice opportunities in organisations (Beardsle, Matzke \& Rospond, 2008). Salaries also determine the productivity and work performance of employees (Yang, 2008). Van Herpen, Van Praag and Cools (2005) substantiate that remuneration has a major impact on organisations' capability to catch, retain and motivate high potential employees, which determines the levels of performance within organisations. Furthermore, Estes and Micheal (2005) opine that well-remunerated employees are likely to perform the job efficiently and effectively. This demonstrates that the amount and method of remuneration is central to the company's production. The aforementioned aspects motivate the following hypothesis;

H3: There is a significant relationship between remuneration and employee well-being in the service industry

\subsection{Work Allocation}

Work allocation is the process of apportioning clear tasks, in numbers appropriate to the current situation, to specific workers (Duarte, Pen, Keller \& Weissing, 2012). O'Donnell and Bulova (2007) point out that it is necessary to allocate work in line with the abilities of employees, since some employees have higher abilities than others. Proper work allocation attracts a number of desirable returns to the organisation, such as growth of total output in terms of the production levels of both individual employees and the company (Yoon \& Suh, 2003). Bolton (2007) further advocates that the fair allocation of workloads results in motivated employees. On the other hand, an inequitable work allocation system may result in high levels of disgruntlement, which may further lead to industrial action and labour turnover (Origo \& Pagani, 2009). In allocating work, managers should be fair, taking into account the skills, knowledge and understanding of employees as well as their experience and workloads and the opportunity for development (Lazear \& Gibbs, 2009). Inconsiderate work allocation may result in a development in which certain employees are overwhelmed with work while others have less work to do. Consequently, those who have been allocated more work may be overworked leading to loss of production and despondency in the workplace (Duarte et al., 2012). Based on the foregoing discourse, this study proposes the following hypothesis: 
H4: There is a significant relationship between work allocation and employee well-being in the service industry

\section{CONCEPTUAL FRAMEWORK}

After considering the insights gained from the literature review, the conceptual framework illustrated in Figure 1 was developed. The framework depicts that employee well-being is driven by four organisational climate factors which are manager-employee relationships, working conditions, remuneration and work allocation. Accordingly, four hypotheses; $\mathrm{H} 1, \mathrm{H} 2, \mathrm{H} 3$ and $\mathrm{H} 4$ were postulated.

Figure 1. Conceptual Framework

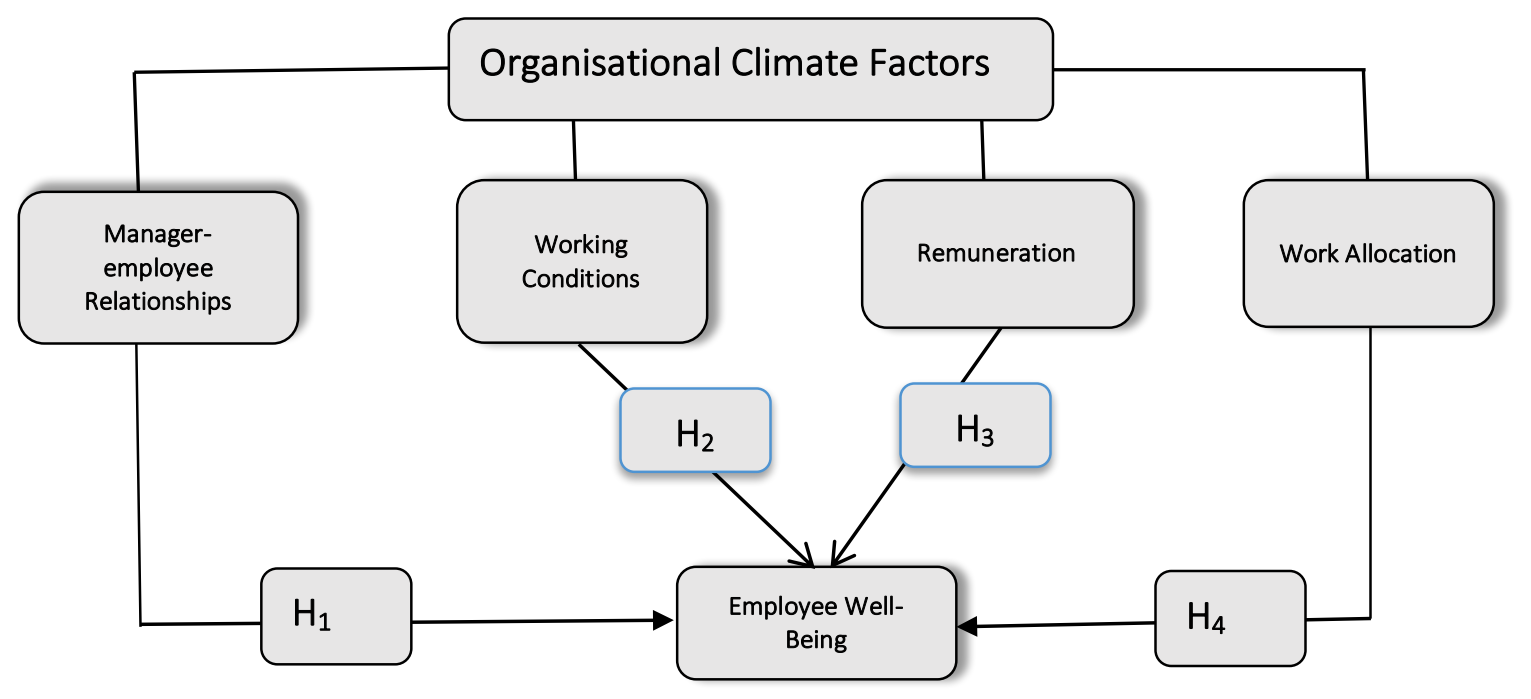

4. METHOD

\subsection{Research Design}

For the purposes of this study, the quantitative research approach using the survey method was used in the collection of primary data. The survey research method was selected because it makes use of questionnaires to obtain data from a sample of respondents selected from the population, which made it directly applicable to this study (Chai \& Xiao, 2012).

\subsection{Participants}

The research among employees at a seven selected companies operating in the services sector which are located in Southern Gauteng, South Africa. Respondents were selected using the-non probability convenience sampling technique. The convenience sampling technique was used because it was difficult to access all the respondents at the selected companies at the same time. An initial sample size of $n=300$ respondents was set, using the available historical information. However, 164 usable questionnaires were eventually collected and used in the data analysis, which gave an acceptable response rate of nearly $55 \%$.

The profile of the respondents showed that $55 \%$ of the respondents were male whereas $45 \%$ of respondents were female. After collapsing the age groups, it emerged that a majority of the respondents (72\%) were aged between 18 and 39 years. With reference to racial groups, approximately $71 \%$ of the respondents were blacks. A total of $48 \%$ of respondents were employed on contract while $32 \%$ were permanent. With respect to employment tenure, $83 \%$; of the respondents had been employed for less than five years. At least $37 \%$ of the respondents worked in the Food and Beverages department whilst 30\% worked in Housekeeping and Casino. 


\subsection{Data Collection Instrument}

A six-section structured questionnaire was used in the data collection process. Questions in Section A consisted of six items that sought information pertaining to aspects such as the respondents' gender, age, race, type of contract, number of years employed, and department where the respondent was employed. Section B consisted of six questions adapted from Booth and Hamer (2000) and Bono and Ilies (2006) that elicited the respondents' views on their relationship with their managers. In Section C, there were five questions that prompted the respondents' perceptions on their working conditions. These questions were adapted from two studies conducted by Lynch (2004) and Kinzl et al. (2004). Section D was composed of six questions (adapted from Fay \& Thompson, 2004; Bockerman \& Ilmakunnas, 2006) that elicited the respondents views on their levels of remuneration. Section E consisted of four questions adapted from Ruhala et al. (2007) as well as David, Rawley and Polsky (2011) that elicited information on work allocation. Section $\mathrm{F}$ of the questionnaire consisted of 20 questions that were adapted from the Minnesota Satisfaction Questionnaire short form (MSQ) designed by Spector (1985). The questions in Sections B to E were scored on a 5 point Likert Scale with 1 expressing strongly disagree and 5 strongly agree. Likewise, the Likert scale configuration was in section $\mathrm{F}$ but the scale was anchored by $1=$ strongly dissatisfied and $5=$ strongly satisfied. The respondents were requested to indicate their scores on these ranges in the scales.

\subsection{Questionnaire Administration}

After their obtaining clearance from management at the selected companies, questionnaires were administered to participants during the month of July 2013. Respondents were given a period of approximately 5 days to complete the questionnaire. During the collecting the data, ethical considerations such as the right to anonymity, right to confidentiality, informed consent, right to privacy or non-participation, and the right to protection from discomfort or harm were followed.

\subsection{Data Analysis}

Data analysis was conducted using a computerised statistical package (SPSS Version 22.0) to compute frequency distributions, measures of central tendency and regression analysis.

\section{RESULTS}

\subsection{Validity and Reliability}

In order to determine the face and content validity of the measuring instrument, a panel consisting of three experts in the discipline of industrial psychology was requested to assess the ability of the questionnaire items to measure the constructs under attention clearly. A pilot test involving a convenient sample of 20 respondents was also conducted. Feedback obtained from these two procedures facilitated the further refinement of questionnaire items. The internal consistencies of the scales in the measuring instrument were measured using the Cronbach alpha coefficient (refer to Table 1), which ranged between 0.722 and 0.871 , while the alpha score for the entire scale was 0.794 . Since these alpha values were all above the minimum acceptable level of 0.70 , it can be concluded then that the measurement scales used in the study were internally consistent or reliable, as recommended by Malhotra (2010).

Table 1. Mean scores and internal consistencies of scales

\begin{tabular}{l|c|c|c|c}
\hline \multicolumn{1}{c}{ Dimension description } & Number of items & $\begin{array}{c}\text { Cronbach } \\
\text { Alpha }\end{array}$ & Mean score & $\begin{array}{c}\text { Position in mean } \\
\text { score rank }\end{array}$ \\
\hline Manager-Employee Relationship & 6 & 0.722 & 4.129 & 5 \\
\hline Working Conditions & 7 & 0.871 & 3.901 & 4 \\
\hline Remuneration & 4 & 0.707 & 3.924 & 3 \\
\hline Work Allocation & 6 & 0.845 & 4.163 & 2 \\
\hline Employee Well-being & 20 & 0.713 & 4.531 & 1 \\
\hline Overall Scale & 35 & 0.794 & 4.527 & Not applicable \\
\hline
\end{tabular}

Scale (Sections B-E): 1= Strongly Disagree: 2=Disagree: $3=$ Neutral: 4=Agree: $5=$ Strongly agree

Scale (Section F): 1= Very dissatisfied: $2=$ Dissatisfied: $3=$ Neutral: $4=$ Satisfied: $5=$ Very Satisfied 
Table 1 showcases the mean scores of the dimensions considered in the study. The mean-scores for the five factors under consideration in this study ranged between 3.901 and 4.531, which represents clear inclinations towards either the agree/strongly agree or the satisfied/strongly satisfied positions on the Likert scales. This result demonstrates that respondents were satisfied with the existing levels of these factors in their organisation. A comparison of the mean scores, shows that employee well-being $(=4.531)$ scored the highest mean, which depicts that respondents were most satisfied with this factor than the other four.

\subsection{Regression Analysis}

In the current study, hypotheses were tested using linear regression analysis. Regression analysis was defined as an inferential statistical technique that is performed to identify the variables that predict or provide the best explanation for the portion of the total variance in the scores of the dependent variables (Malhotra, 2010). Employee well-being was entered into the regression model as the dependant variable and the four factors; namely, manager-employee relationship, working conditions, remuneration and work allocation were entered as the independent variables. The results are reported in Table 2.

Table 2. Regression Model

\begin{tabular}{|c|c|c|c|c|}
\hline \multirow{3}{*}{$\begin{array}{l}\text { Independent variables: } \\
\text { Extrinsic motivation factors }\end{array}$} & \multicolumn{4}{|c|}{ Dependent variable: Employee well-being } \\
\hline & $\begin{array}{c}\text { Standardised } \\
\text { Coefficients }\end{array}$ & $\mathbf{T}$ & Sig. & $\begin{array}{c}\text { Collinearity } \\
\text { Statistics } \\
\end{array}$ \\
\hline & Beta & & Tolerance & VIF \\
\hline Manager-employee relationship & 0.291 & 4.265 & 0.000 & 0.571 \\
\hline Working conditions & 0.248 & 5.844 & 0.001 & 0.682 \\
\hline Remuneration & 0.109 & 1.995 & 0.040 & 0.595 \\
\hline Work allocation & 0.276 & 2.137 & 0.002 & 0.709 \\
\hline Model summary: & $F=16.72$ & error & mate $=0.84$ & \\
\hline
\end{tabular}

The four independent factors accounted for approximately $44 \%(\mathrm{R} 2=0.438)$ of the variance explained in employee well-being. Colleniarity statistics for the four independent variables were satisfactory, indicating that the problem of multi-collinearity was insignificant in this study since there were no high correlations between the independent variables. All tolerance values fell above the value of 0.5 prescribed by O'Brien (2007). Variance inflation factor (VIF) values fell between the 1.0 and 4.0 range recommended by Pan and Jackson (2008).

\section{DISCUSSION}

Hypothesis $\mathrm{H} 1$ found support in this study and was therefore accepted since the regression model revealed that the manager-employee relationship factor was statistically significant $(\beta=0.291 ; \mathrm{t}=4.265 ; \mathrm{p}<0.000)$. This result demonstrates that the state of health of the relationship between managers and employees is an indicator of the level of employee well-being among employees in the workplace. These findings are consistent with the findings of a study conducted by Noblet, Graffam and McWilliams (2008) which concluded that when managers consult their subordinates, the result is a better feeling of belongingness, which leads to better mental health among the employees. In addition, in a study by Booth and Hame (2007) it emerged that employees in democratic management workplaces reported reduced stress levels than those in conventional management workplaces where decision-making is for managers only. Managerial support that allows employee feedback and bilateral communication in an organisation is also important because it improves employee well-being (Kassahun, 2005). Conversely, managers who are under pressure may affect their subordinates by bullying them, which causes most of the subordinates to suffer from depression and other ill health problems (Zairi \& Jarrar, 2006). Merriman, Schmidt, Ross and Dunlap-Hinkler (2004) further add that managers have to understand that their behaviours can severely transform the efficiency, productivity, quality, morale, and culture of their organisations if they temper with workplace trust. Lufkin (2006) also emphasises that an effective manager is one who is able to monitor stress levels, manage expectations and make every effort to understand the needs of subordinates. Therefore, in order to spur employee well-being and its wide-array of associated benefits, it is imperative that there be meaningful relationships between managers and their employees in the workplace in the service industry. 
Hypothesis $\mathrm{H} 2$ was supported and consequently accepted in this study because the regression analysis disclosed that the working conditions factor was statistically significant $(\beta=0.248 ; \mathrm{t}=5.844 ; \mathrm{p}<0.001)$. This finding portrays that the state of working conditions reflects the degree of employee well-being among employees in the services industry. As advocated by Kinzl et al. (2004) the working environment could influence the level of pride employees have in themselves and the work they do. Employees who work in clean and friendly environments are more likely to be satisfied with and look forward to their respective jobs (Spitzer, 2007). Turkyilmaz, Akman, Ozkan and Pastuszak (2011) further stress that a healthy working environment facilitates the easier accomplishment of task goals by employees. Working conditions regulate the level of satisfaction that an individual employee experiences (Hall, 2003). Also, most employees prefer to work in environments where temperature, lighting, noise and other environmental factors are both safe as well as comfortable (Van Emmerik, 2004). Still, Krueger et al. (2002) suggest that a good working environment stimulates optimum organisational performance. It is an important supposition then, to assume that satisfaction of employee well-being hinges, among other things, on satisfaction with the standard of working conditions in the services industry.

Hypothesis $\mathrm{H} 3$ was supported and thus accepted in this study as there was a statistically significant relationship $(\beta=$ $0.109 ; \mathrm{t}=1.995 ; \mathrm{p}<0.040$ ) between remuneration and employee well-being. This finding illustrates that one may use remuneration to measure and forecast the level of well-being among workers in the service industry. As observed by Barbie (2010), the inadequate performance of employees in most organisations could be attributed in part, to dissatisfaction with remuneration. High and recurring incidence of industrial action, turnover, absenteeism and excessive unionism within organisations may be symptomatic of employees' dissatisfaction with the reward system in place (Nilsson, 2010). A study conducted by Van den Berg (2006) established that remuneration is strongly and positively related to the welfare of employees. A comparative study of public and private sector organisations conducted by Stedham, Yamamura and Satoh (2006) concluded that employees in the public sector are less extrinsically motivated with their work since their compensation is suggestively lower than what is earned in the private sector. An evaluation of employee perceptions in Greece showed that employees upheld that extrinsic motivation instruments, more specifically the provision of fair wages, could be effective tools to improve productivity (Cardoso \& Portugal, 2006). Similar conclusions were drawn by Lazear and Oyer (2004) in a study that examined the satisfaction of employees. Frye (2004) further contends that an increase in wages improves the efficiency of the organisation by enhancing the motivation of the employees. Gavrel and Lebon (2008) similarly found that introducing a market related wage may improve market efficiency by reducing the mismatch between workers and jobs. It may be pointed out then that to maintain its operational success, it is vital for an organisation operating in the services industry to ensure that its employees are adequately-remunerated.

Hypothesis $\mathrm{H} 4$ found support and was subsequently accepted in this study, since the work allocation factor was statistically significant $(\beta=0.276 ; \mathrm{t}=2.137 ; \mathrm{p}<0.002)$. This result designates that employee swell-being amongst employees in the service industry is dependent upon the mode of work allocation. Abd-El-Fattah (2010) found that the majority of resignations in organisations can be attributed to disappointment with wok allocation within the organisation. This signifies that there is an established positive association between work allocation and the satisfaction of employees. A study by Boreham, Gray and Blake (2006) found that satisfaction with work allocation is a dominant factor influencing employee well-being. Roelen, Koopmans and Groothoff (2008) also add that work allocation has emerged as a hindrance to the development and success of organisations (both public and private) in any country because it determines the extent to which employees are satisfied with and motivated to achieve organisational goals (Young, 2009).

Work allocation patterns contribute to the efficient operation of the organisation, as they determine the emotional, social and the physical health of employees (Croxon, Propper \& Perkins, 2003; Origo \& Pagani, 2009). On the contrary, managers who do not clarify the roles and duties of their employees might cause role conflict and role ambiguity among employees. Yang (2008) also advises that role ambiguity and role conflict may cause an individual to suffer from emotional exhaustion and depersonalisation, leading to employee dissatisfaction. This means that in order for the organisation in the services industry to grow, managers must be able to give out work to employees in such a way that both employees and the organisation will benefit in the end (Bebchuk \& Fried, 2003). 


\section{LIMITATIONS AND IMPLICATIONS FOR FURTHER RESEARCH}

This study has several limitations which should be highlighted. Firstly, caution should be applied in generalising this study to other settings and contexts, since the findings of the present study are based on a small sample that was drawn from a single organisation. Secondly, the use of the non-probability convenience sampling technique increased the study's exposure to sampling bias. Thirdly, the study was conducted using a modified questionnaire which was based on questions that were not originally intended for the current study. In addition, the common limitations that are associated with quantitative data collection techniques that were employed in this research are acknowledged.

This study has implications for further research. Similar studies may be conducted using larger samples recruited from other organisations that were not included in this study. The study could be conducted using more advanced statistical models such as Structural Equation Modelling (SEM), which may refine the results of the study. Future studies could also consider other organisational climate factors (e.g. recruitment, selection, training, etc.) that were omitted from this study. Comparative studies between the results of this study and those obtained from other organisations or through meta-analyses could also be considered in the future. This could lead to other thought provoking insights that were not captured in the current study.

\section{CONCLUSIONS}

The purpose of this study was to examine the existence of predictive relationships between employee well-being and four organisational climate factors; namely; manager-employee relationships, working conditions, remuneration and work allocation in the service industry. It emerged that all factors were statistically significant, which implies that they are predictors of employee well-being. It is appropriate therefore to conclude that employee well-being in the service industry is dependent on the state of the relationship between management and employees, the standard of working conditions, the levels of remuneration and the mode of work allocation.

This study has theoretical and practical implications. On the theoretical front, the study provides current evidence of the dynamics in the relationship between the dimensions considered in this study, particularly in the context of the service industry. In this regard, the study serves as a reference source to future researchers on similar issues. On the practical side, managers in the service industry may be able to enhance the degree of employee well-being amongst workers in their organisations by making strategic improvements on the four independent variables considered in this study.

\section{AUTHOR BIOGRAPHY}

Dr. Chengedzai Mafini is a holder of a Ph.D. in Economics and a Doctor of Technology degree in Business. He currently serves as Head of the Department of Logistics in the Faculty of Management Sciences at Vaal University of Technology in South Africa. His research interests include human and organizational performance management and supply chain performance.

\section{REFERENCES}

Abd-El-Fattah, S.M. (2010). Longitudinal effects of pay increase on teachers' job satisfaction: a motivational perspective. The Journal of International Social Research, 3(10), 11-21.

Agarwal, R., \& Ferratt, T.W. (2001). Crafting and HR strategy to meet the need for IT workers. Communications of the ACM, 44(7), 58-64.

Attwood, D., Khan, F., \& Veitch, B. (2006). Can we predict occupational accident frequency? Process Safety Environment, 84 (3), 208-221.

Barbie, J. (2010). South Africa, civil service strike. Global post. 4 September. Available at: http://www.globalpost.com/dispatch/south-africa/100903/south-africastrikegrinds-ountryhalt. Accessed: 16 June 2014.

Bebchuk, L.A., \& Fried, J. (2003). Executive compensation as an agency problem. Journal of Economic Perspectives, 17, 71-92.

Bhattacharya, C.B., \& Sankarsen, S. (2003). Consumer-company identification: a framework for understanding consumers' relationships with companies. Journal of Marketing, 67, 76-88.

Bockerman, P., \& IlmakunnaS, P. (2006). Do job disamenities raise wage or ruin job satisfaction? International Journal of Manpower, 27(3), 290-302.

Bolton, L. E. (2007). Believing in first mover advantage. Working Paper, Wharton School, University of Pennsylvania. 
Booth, S., \& Hamer, K. (2000). Labour turnover in the retail industry: Predicting the role of individual, organisational and environmental factors labour turnover in the retail industry. International Journal of Retail \& Distribution Management, 35(4), 289-307

Bono, J.E, \& Ilies, P. (2006). Charisma, positive emotions and mood contagion. Leadership Quarterly, 17, 317-334.

Boreham, N., Gray, P., \& Blake, A. (2006). Job satisfaction among newly qualified teachers in Scotland. Institute of Education. University of Stirling.

Buitendach, J.H., \& De Witte, H. (2005). Job insecurity, extrinsic and intrinsic job satisfaction and affective organizational commitment of maintenance workers in a parastatal. South African Journal of Business Management, 36(2), 27-37.

Bushell, H.M. (2007). Quantifying the key leadership behaviours for creating a successful culture which empowers employees and strengthens organisational performance. Health, Work \& Wellness Conference, Toronto, Canada.

Cardoso, A.R., \& Portugal, P. (2006). Disentangling the minimum wage puzzle: an analysis of worker accessions and separations. Journal of the European Economic Association, 4(5), 988-1013.

Chai, K., \& Xiao, X. (2012).Understanding design research: a bibliometric analysis of Design Studies (1996- 2010). Design Studies. 33(1), 24-43.

Cropanzano, R., \& Mitchell, M.S. (2005). Social exchange theory: an interdisciplinary review. Journal of Management, 31(6), 874-900.

Croxon, B., Propper, C., \& Perkins, A. (2003). Do doctors respond to financial incentives? UK family doctors and the GP fundholder scheme. Journal of Public Economics, 79, 375-398.

David, G. Rawley, E., \& Polsky, D. (2011). Integration and task allocation: evidence from patient care. National Bureau of Economic Research, Working Paper 17419. Available at: http://www.nber.org/papers/w17419. Accessed: 4 March 2014.

Duarte, A., I. Pen, L., Keller, L., \& Weissing. F. J. (2012). Evolution of self-organized division of labor in a response threshold model. Behavioral Ecology and Sociobiology, 66, 947-957.

Fabiano, B., Curro, F., Reverberi, A.P., \& Pastorino, R.A. (2008). Statistical study on temporary work and occupational accidents: specific risk factors and risk management strategies. Safety Sciences, 46, 535-544.

Fay, C.H., \& Thompson, M.A. (2004). Minimum wage effects on labor market outcomes under search, matching, and endogenous contact rates. Econometrica, 74 (4), 1013-1062.

Forlan, P., \& Browne, J. (2005). A Review of performance measurement: towards performance management. Computers in Industry, 56, 663-680.

Frye, M. (2004). Equity-based compensation for employees: firm performance and determinations. Journal of Financial Research, 27, 31-54.

Giannikis, S.K., \& Mihail, D.M. (2011). Modeling job satisfaction in low-level jobs: Differences between full-time and part-time employees in the Greek retail sector. European Management Journal, 29(2), 129-143.

Gilbreath, B., \& Benson, P.G. (2004).The contribution of supervisor behaviour to employee psychological well-being. Work \& Stress, 18, 255-266.

Guthrie, J., \& English, L. (1997).Performance information and program evaluation in the Australian public sector. International Journal of Public Sector Management, 10(3), 154-64.

Gavrel, F., \& Lebon, I. (2008). Minimum wage, unemployment benefits and labor market efficiency. Louvain Economic Review, $74,53-75$.

Hall, C. (2003). Job satisfaction of sport management faculty in the U.S.A. Unpublished Doctoral thesis. Florida State University College of Education: Florida.

Holcroft, C., \& Punnett, L. (2009).Work environment risk factors for injuries in wood processing.Journal of Safety Research, 40, 247-255.

Hunter, S. T., Bedell, K. E., \& Mumford, M. D. (2007). Climate for creativity: A quantitative review. Creativity Research Journal, 19(1), 69-90.

Ireland, R.D., Hoskisson, R.E., \& Hitt, M.A. (2009). The management of strategy: concepts and cases. Mason: Cengage Learning.

Ivancevich, J., Konopaske, R. \& Matteson, M. (2007). Organizational Behavior \& Management, 8th Ed. Boston, McGraw Hill.

Jackson, S.E., \& Schuler, R.S. (1995). Understanding human resource management in the context of organizations and their environments. Annual Review of Psychology, 46, 237-264.

Kassahun, T. (2005). Level of organisational commitment: its correlates and predictors, Indian Journal of Industrial Relations, 41(1), 29-36.

Katou, A.A., \& Budhwar, P.S. (2007). Human resource management systems and organisational performance: a test of a mediating model in the Greek manufacturing context. The International Journal of Human Resource Management, 17(7), 1223-1253.

Kinzl, J.F., Knotzer, H., Traweger, C., Lederer, W., Heidegger, T., \& Benzer, A. (2004). Influence of working conditions on job satisfaction in anaesthetists. British Journal of Anaesthesia, 9(4), 102-133.

Krueger, B., Brazil, K., Lohfield, L., Edward, H.G., Lewis, D., \& Tjam, E. (2002). Organisation specific predictors of job satisfaction: Findings from a Canadian multi-site quality of work life cross-sectional survey. BMC Health Service Research, 2, 5-24. 
Lazear, E., \& Oyer, P. (2004). Internal and external labour markets: a personnel economics approach. Labour Economics, 11, 527-554.

Lynch, W.D. (2004). Health affects work and work affects health. Business Health, 19, 31-37.

Lufkin, P. (2006). Technical communication managers face many challenges. Intercom, June, 3.

Malhotra, N.K. (2010). Marketing research: an applied orientation. 6th ed. Eaglewood Cliffs, N.J: Prentice-Hall.

Martins, N. (2005).A model for managing trust. International Journal of Manpower, 23(8), 754-769

Md-Sidin, S., Sambasivan, M., \& Ismail, I. (2010). Relationship between work-family conflict and quality of life. Journal of Managerial Psychology, 25(1), 58-81.

Mead, H., Witkowski, K., Gault, B., \& Hartmann, H. (2003). The influence of income, education, and work status on women's well-being. Womens' Health Issues, 11, 160-72.

Merriman, K. K., Schmidt, S. M., \& Dunlap-Hinkler, D. (2007). Profiling virtual employees: The impact of managing virtually. Journal of Leadership \& Organizational Studies, 14(6), 6-15.

Nielsen, K., Yarker, J., Brenners, S.O., Randall, R., \& Borg, V. (2008). The importance of transformational leadership style for the well-being of employees working with older people. Journal of Advanced Nursing, 63(5), 465-475.

Nilsson, J. (2010). What's the problem? local officials' conceptions of weaknesses in their municipalities' crisis management capabilities. Journal of Contingencies and Crisis Management, 18(2), 83-95.

Noblet, A., Graffam, J., \& McWilliams, J. (2008). Sources of well-being and commitment of staff in the Australian Disability Employment Services. Applied Psychology, 55(2), 192-219.

Nurmala, D. (2010). Investigating the relationship between quality of work life and organizational commitment amongst employees in Malaysian firms. International Journal of Business and Management, 5(10), 324-342.

O'Brien, R. M. (2007). A caution regarding rules of thumb for variance inflation factors. Quality \& Quantity, 41, $673-690$.

O'Donnell, S., \& Bulova, S.J. (2007). Worker connectivity: a review of the design of worker communication systems and their effects on task performance in insect societies. Insectes Sociaux, 54(3), 203-210.

Origo, F., \& Pagani, L. (2009). Flexicurity and job satisfaction in Europe: the importance of perceived and actual job stability for well-being at work. Labour Economics, 16(5), 547- 555.

Pan, Y., \& Jackson, R. T. (2008). Ethnic difference in the relationship between acute inflammation and serum ferritin in US adult males. Epidemiology and Infection, 136, 421-431.

Price, J.L. (2001). Reflections on the determinants of voluntary turnover. International Journal of Manpower, 22(7), 600-624.

Rethinam, G.S., \& Ismail, M. (2008). Constructs of quality of work life: a perspective of information and technology professionals. European Journal of Social Science, 7(1), 58-71.

Roelen, C. A., Koopmans, P.C., \& Groothoff, J. W. (2008). Which work factors determine Job satisfaction? IOS Press, 30, 433439.

Rose, D. M. \& Waterhouse, J. M. (2004). Experiencing new public management: employee reaction to flexible work practices and performance management. Industrial Relations European Conference, Utrecht, Netherlands

Schutte, K.J., \& Eaton, S.C. (2004). Perceived usability of work/family policies. Sloanwork and Family Excyclopedia. Available at: http://wfnetwork.bc.edu/encyclopedia_entry.php?id=248\&area=All. Accessed: 17 April 2014.

Spitzer. D. (2007). Transforming performance measurement: rethinking the way we measure and drive organizational success. New York: Amacom.

Stedham, Y., Yamamura, J.H., \& Satoh, M. (2006). Gender and salary a study of accountants in Japan. Asia Pacific Journal of Human Resources, 44(1), 46-66.

Tang, J., \& Chen, W.Q. (2001). From “organizational climate" to "organizational culture"-the logic of concept development. Journal of Development in Psychology, 9(1), 62-65.

Tangen, S. (2004). Performance measurement: from philosophy to practice. International Journal of Productivity and Performance Management, 53(8), 726-737.

Thompson, E. R., \& Phua, F. T. T. (2012).A brief index of affective job satisfaction. Group \& Organization Management, 37(3), $275-307$.

Turkyilmaz, A., Akman, G., Ozkan, C., \& Pastuszak, Z. (2011). Empirical study of public sector employee loyalty and satisfaction. Industrial Management \& Data Systems, 111(5), 675-696.

Van Den Berg, G. (2003). Multiple equilibria and minimum wages in labor markets with informational frictions and heterogeneous production technologies. International Economic Review, 44, 1337-1357.

Van Emmerik, H. (2004). For better and for worse: adverse working conditions and the beneficial effects of mentoring. Career Development International, 9 (4), 358-373.

Van Herpen, M.F.M., Van Praag, C.M., \& Cools, K. (2005). The effects of performance measurement and compensation on motivation: an empirical study. De Economist, 153(3), 303-29.

Varonen, M., \& Mattila, K. (2003).The safety climate and its relationship to safety practices, safety of the work environment and occupational accidents in eightwood-processing companies. Accident Anal. Prev. 3, 761-769.

Voss, Z.G., Cable, D.M., \& Voss, G. B. (2006). Organizational identity and firm performance: what happens when leaders disagree about "Who We Are?" Organization Science, 17(6), 741-55.

Yang, H. (2008). Efficiency wages and subjective performance pay. Economic Inquiry, 46(2), 179-196.

Yavari, Y., Amirtash, A.M., \& Tondnevis, F. (2009).Comparison of quality of work life among faculty members in physical 
education faculties and departments. Journal of Movement Science, 7(13), 99-109.

Yee, R.W.Y., Yeung, A.C.L., \& Cheng, T.C.E. (2010). An empirical study of employee loyalty, service quality and firm performance in the service industry. International Journal of Production Economics, 124(1), 109-120.

Yeow, P.H.P., \& Sen, R.N. (2006). Productivity and quality improvements, revenue increment, and rejection cost reduction in the manual component insertion lines through the application of ergonomics. International Journal of Industrial Ergonomics, 36 (4), 367-377.

Young, Y.A. (2009). Police in the eye of the storm. A quarterly publication of Police Community Relations Committee (P.C.R.C), 14-19.

Yoon, M.H., \& Suh, J. (2003).Organisational citizenship behaviors and service quality as external effectiveness of contact employees. Journal of Business Research, 56(8), 597-611.

Zairi, M., \& Jarrar, Y.F. (2006). Measuring organizational effectiveness in The NHS: management style and structure best practices. Total Quality Management, 12(78), 882-889.

Zhang, J. \& Liu, Y. (2010). Organizational climate and its effects on organizational variables: an empirical study. International Journal of Psychological Studies, 2(2), 189-201. 


\section{NOTES}

